\title{
The Extent to which Females Occupy Leadership Positions in Zimbabwean Teachers Colleges
}

\author{
${ }^{1}$ Lincoln Hlatywayo, ${ }^{2}$ Sophie Hlatywayo,${ }^{3}$ Zano Augustine Muranda \\ ${ }^{1}$ (DEd Candidate, MSc, MEd, BSc, Diploma, Certificate), ${ }^{2}\left(M E d, B E d, B S c\right.$, Diploma), ${ }^{3}$ (MEd,Bed,CE) \\ ${ }^{I}$ Senior Lecturer: Disability Studies and Special Needs Education, Zimbabwe Open University \\ ${ }^{2}$ Lecturer: National Strategic Studies, Morgan Zintec Teachers College \\ ${ }^{3}$ Lecturer: Educational Management, Zimbabwe Open University
}

\begin{abstract}
The study explored the effectiveness of female leaders in Zimbabwean teacher training colleges. The study focused on two teacher training colleges in Harare. The research adopted the mixed method approach whereby both qualitative and quantitative methods were used in compliment. The multiple case study design was the plan used to guide the study execution. The population included all the female leaders holding designated posts and lecturers at the two institutions. Purposive sampling was used to come up with a representative sample of 10 female leaders and 30 lecturers. The semi-structured interview and the questionnaire were the tools used to collect data respectively. The findings revealed that female leaders in teachers colleges mainly use democratic and participatory leadership styles. It was also found that female leaders also resort to autocratic styles where they feel their authority is under threat. Most respondents rated the leadership of females in teacher training colleges as effective. The study recommended that the government and civil society should work tirelessly to uproot the systems such as patriarchy that wrongly define Zimbabwean society which hinders development. Society is advised to adopt an attitude that believes in the dictum that says 'Whatever a man can do a woman can also do." Thus a change of mindset in this regard. The government and civil society should continuously run campaigns to sensitize the nation on issues to do with females in leadership. Interventions in the form of workshops, seminars and in-service training that are specifically aimed at empowering women and men would be also be useful. Lastly it is recommended that government ensure the implementation of policies such as affirmative action practically and not only on paper. This can be done by close evaluation and monitoring strategies in most institutions.
\end{abstract}

Key terms: Gender, gender equity, gender equality, leadership, attitudes, perceptions.

\section{Introduction}

Zimbabwe is described as one of the leading African nations in the area of promoting gender equity and gender equality. To show its commitment towards the achievement of gender equality and equity, the Government of Zimbabwe has ratified a number of regional and international conventions whose objectives are to promote and realize the rights of women and to achieve gender equality and equity. Conventions ratified according to UNDP (2011) include:

- Convention on the Elimination of all forms of Discrimination Against Women (CEDAW) 1991

- Convention on Civil and Political Rights (CCPR)

- Equal Remuneration Convention (ERC)

- Dakar Platform for Action

- Beijing Declaration of 1995 and

- SADC declaration on Gender and Development with its addendum on Prevention and Eradication of Violence against Women and Children (1997) and

- The Millennium Declaration of 2000.

In 2004 the government of Zimbabwe launched the National Gender Policy whose function is to direct and guide the process of gender equity and equality. The government also enacted progressive legislative laws such as the Domestic Violence Act (2007) and making amendments to family and inheritance laws. Labour laws have also been amended to reflect gender equality priorities. Examples of laws include the Legal Age of Majority Act of 1982, the Matrimonial Causes Act of 1985, the Sexual Discrimination Removal Act of 1986 and the Sexual Offences Act of 2001. These have been put in place to promote gender equality and protect women's rights. The government of Zimbabwe created the Ministry of Women Affairs, Gender and Community Development (MWAGCD) in 1995 to oversee coordination of all gender programmes and to facilitate gender mainstreaming in all sector ministries, (UNFPA, 2011). 
In response to the persistent gender disparity in decision-making positions in Zimbabwe, the Affirmative Action Policy was put in place policy in 1992 which was meant to raise women to leadership positions by giving them priority as compared to men. The Public Service Commission responded to this policy by coming up with specific policies meant to expedite the promotion of women teachers to headship positions in both primary and secondary schools. For example, Public Service Circular No.11 (1991:2) states that heads should identify women who could be promoted to headship grade without reference to seniority and recommend them to be given schools to head. Public Service Circular No. 22 (1996) and Public Service Circular No.1 (1997) encouraged women teachers to apply for school management posts. All these were measures taken to speed up the promotion of more women teachers to school leadership positions. Very little research has been carried to find out whether the call for female leaders in all sectors of the economy commensurate with the appointments being done. It is against this background that this research study was carried to establish the extent of female leadership in teacher training colleges. The study also sought to establish gender differences among male and female leaders. The research fields were two teacher training colleges in Harare.

\subsection{Statement of the Problem}

The issue of gender equity and equality has resulted in many females being elevated to higher positions in all sectors of the Zimbabwean government including tertiary education. However, there are cultural and societal expectations which may have an effect on female leadership considering that the women's place was traditionally supposed to be below the men. The cultural perspective placed females on subordinate positions and elevated males to higher positions. The problem in this study is therefore stated in question form as, "To what extent do females occupy leadership positions in teacher training colleges?"

\subsection{Research Questions}

Two research questions underpinned the study and these were

1. What is the extent of female leadership in teacher training colleges?

2. Are there any gender differences regarding leadership in teacher training colleges?

\subsubsection{The Concept Leadership}

\section{II. $\quad 2.1$ Literature Review}

Traditionally scholars have approached leadership from two perspectives, one that focuses on positional leadership within an organization hierarchy and one that views leadership as a social influence process that is naturally occurring in social systems. (Bass 2000). With this tradition, there are leadership theories that define a leader. These help to understand leadership traits and behaviors and how leaders employ their influence and power to their situations.

The importance of leadership has been strongly emphasized in the school effectiveness and educational reforms. Numerous studies of organization and management including Sergiovanni (1984) have also indicated that leadership is a critical factor for organizational performance and effectiveness, which shapes organizational process and structure, patterns of social interactions, members' beliefs, attitudes and job behaviors.

Owens (1995:116) defines leadership as, "a group function where it occurs only in the processes of two or more people interacting". This definition shows that leadership is a collaborative process where more people work together one being the leader and the others being the led. Leadership is when one influences the behavior of others so as to achieve set goals. Cohen (1990:9) state that, "Leadership is the art of influencing others to their maximum performance to accomplish any task, objective or project." This definition also emphasizes the issue of influencing others for the achievement of objectives. Therefore, leadership is the ability to influence a group toward the achievement of a vision or set of goals. A leader must be able to leverage more than own capabilities and must be capable of inspiring other people to prescribe tasks. A leader usually in educational institutions refers to anyone with administrative duties such a school Head, Principal, Education Officer, etc. and occurs at different levels of the organizational structure. This shows that even the roles and duties of the leader differ according to the level of leadership.

Winston and Patterson (2003) in Robbins (2004) emphasize that leadership involves showing commitment to the values of (a) humility, (b) concern for others, (c) controlled discipline, (d) seeking what is right and good for the organization, (e) showing mercy in beliefs and actions with all people, (f) focusing on the purpose of the organization and on the well-being of the followers, and (g) creating and sustaining peace in the organization-not a lack of conflict but a place where peace grows. These values are the seven Beatitudes found in Matthew 5 and are the base of the virtuous theory of Servant Leadership. Winston and Patterson (2003) states that a leader is one or more people who selects, equips, trains, and influences one or more follower(s) who have diverse gifts, abilities, and skills and focuses the follower(s) to the organization's mission and objectives causing the follower(s) to willingly and enthusiastically expend spiritual, emotional, and physical energy in a concerted coordinated effort to achieve the organizational mission and objectives. The leader achieves this influence by humbly conveying a prophetic vision of the future in clear terms that resonates with the followers belief and 
values in such a way that the followers can understand and interpret the future into present-time action steps. This is achieved through the use of leadership skills such as facilitation, communication etc. the ultimate purpose of leadership would be to achieve organizational objectives and goals.

\subsubsection{Leadership and Gender}

Most African societies have determined that only males make good leaders; therefore they continue to have various attitudes towards females in leadership roles because they do not fit the norm. The male bias is reflected in the false conception of leadership as mere command or control (Burns, 1998). Historically, leadership has carried the notion of masculinity and the belief that men make better leaders than women is still common today. Although the number of female leaders has increased, they are often named as an afterthought. The study carried out by Hojgaard (2002), in Kenya, the societal conventions regarding gender and leadership traditionally exclude women, and top leadership is viewed as a masculine domain. The same author further argues that the cultural construction of leadership in itself instigates difference and this is only now being transformed or contested as women gain access to leadership positions. In African societies, it is believed that men lead and women follow (Ngcongo, 1993, in Grant, 2005).

\subsubsection{The extent of females in leadership positions}

Although the World Economic Forum's 2012 Global Gender Gap Report showed greater equality between the sexes in human capital investments and economic opportunities, female underrepresentation persists in political leadership positions and in the highest-paying jobs. UN Women (2011) reported that in 2011, only 19 percent of parliamentarians worldwide were women, and a woman headed the government in only 19 countries. The numbers are even lower in big business. This showed low representation of female in higher positions of authority.

Johnson (1993:10) in Husu (2010) reporting on the status of women's leadership in higher education, writes that "women administrators continue to be clustered in middle management positions and areas outside of academic deanships and other more central administrative positions". This may help to explain that few women reach the highest level of administration ending up being vices and departmental leaders. Winn (2001) cited in Madziyire and Mapolisa (2012) suggest that the disadvantaged position of women in relation to men in the workplaces is related to low educational attainment and skills in many developing countries. This inequality in access to education and training fosters occupational segregation between men and women.

Mitroussi and Mitroussi (2009) argues that academia tends to be more resistant than business and politics to pressures for elimination of obstacles to advancement of women in many countries, except at the level of recruiting students and participation in the lower ranks of the academic hierarchy, as men are more likely than women to move up successive stages of the academic career ladder. This shows that more females occupy the highest level posts in politics and business sectors than in education. This could be attributed to the idea that few women reach the highest level of education which forms the basis for promotion in higher education. Elms (2002) cited by Love (2013) found out that one of the most common reasons for the underrepresentation of women in school administration is gender-role stereotyping.

Mitroussi and Mitroussi (2009) in their study on female leadership in education in UK and Greece, reveal that in both countries, fewer women than men reach top rank positions in education, particularly in secondary and higher education. They add that women are not only under-represented in positions of authority and mainly confined to certain discipline areas but they also tend to be disadvantaged at all grades in terms of salary and are also more likely than their male colleagues to have insecure short-term contracts. This shows that women may constitute large numbers as lecturers, few numbers as professors and administrators which differentiate the salaries.

The study conducted by Vosniadou (2004) cited by Mitroussi and Mitroussi (2009) covering all Greek universities for the academic year 2003/2004 showed that the percentage of women decreases every step up the academic ladder. These results reveals the considerable underrepresentation of women in posts at the higher end of the academic ladder, as the higher the position in the academic hierarchy, the lower the percentage of women is. Although these studies were conducted in Greek, the results may be applicable to Zimbabwe which had more challenges in addressing gender imbalances which were worsened by the colonial period as well as cultural and societal expectations.

Madziyire and Mapolisa (2012) notes that the population of women in Zimbabwe is more than that of men as they comprise $52 \%$ of the entire population but women are underrepresented in jobs of authority and decision making responsibilities. The gender sensitization programmes have led many parents in Zimbabwe to improve on access to education for both boy and girls. Thus, the issue of lack of access to education is now minimal for girls. Zimbabwe has had many women with higher educational and professional qualifications but occupying less challenging jobs in terms of management and decision making in organizations, both private and 
public Madziyire and Mapolisa (2012). Their study was focused on primary schools in Harare, in Zimbabwe focusing on teachers' perceptions. Their study did not cover the perceptions of lecturers in teachers' colleges.

The belief that older men still dominate the leadership ranks is evident given the current disparity in the numbers of men and women at the top levels. The Conference Board of Canada of May (2013), conducted a study on the perceptions of women leadership and concluded that vast majority of female interviewees indicated that few women reach the top level management. Among the barriers cited were lack of acceptance of women's leadership styles and different opportunities being offered to males and females. Other barriers noted are sexism among men in positions of power and lack of understanding of, and support for, women's non-traditional career paths. The conference blamed the male-dominated boards for not considering enough female candidates; erroneous beliefs about women's commitment to work. Women themselves might not believe in their ability to lead, since they rarely see other women succeed in such positions and sometimes lack of interest can be a result of women shunning leadership roles for fear of stress caused by role conflict between family and work. The lack of exposure to female leaders, in turn, perpetuates biased perceptions of women's effectiveness in leadership roles.

Anneli (2000) adds that lack of support from the society and the institutional context are some of the causes of under-representation and poor career progress of women in school headship positions. Eshete (2003) concludes that the reasons for women's low representation in higher education are of course many and complex. Some are direct reflections of the personal, social and economic factors. Others are related to the structural, administrative and management structures of the institutions that can also become crucial points for intervention. These factors hinder the full participation of women in high level leadership positions despite efforts being done to include them.

\subsubsection{The Research approach}

\section{Methodology}

This study adopted the use of mixed methodology. The research questions were designed in the way that they require qualitative responses. However, some questions which were derived from the research questions demanded quantitative presentation and analysis. These were based on the responses gathered from the respondents. Johnson and Onwuegbuzie (2004) define mixed methods research as the class of research where the researcher mixes or combines quantitative and qualitative research techniques, methods, approaches, concepts or language into a single study or set of related studies. Rossman and Wilson (1985) cited by Johnson et al. (2007) identified three reasons for combining quantitative and qualitative research that is to enable confirmation or collaboration of each other through triangulation, to develop analysis in order to provide richer data and to initiate new modes of thinking by attending to paradoxes that emerge from the two data sources. In this study both qualitative and quantitative data were collected concurrently and then analyzed using both qualitative and quantitative data analysis methods.

\subsubsection{The Research design}

The research design adopted for this study was the multiple case study. Yin (1993) defines a case study is a detailed investigation of a single individual or group. Case studies can be qualitative or quantitative in nature, and often combine elements of both as was in the current study. The defining feature of a case study is its holistic approach; it aims to capture all of the details of a particular individual or group, which were relevant to the purpose of the current study, within a real life context, (Yin, 1993). The case study allowed the researcher to explore all three domains of the respondents, which are cognitive, behavioral and affective, (Leedy, 1980). This helped in bringing out the inner feelings of the respondents. The design was also used because of the characteristics as noted by Borg and Gall (2007). They noted that the case study is a design which serves three purposes. First to produce detailed descriptions of the issue under study. Secondly, to develop possible explanations and thirdly to produce possible evaluations.

\subsubsection{Population, sampling and the representative sample}

The population of the study included all the female leaders at two teacher training colleges in Harare. The leadership positions included designation posts like sports directors, lecturers in charge, heads of department, vice principals, principals. The population also included all the lecturers at the two institutions. Purposive sampling was used to come up with a representative sample of 10 female leaders, 15 male lecturers and 15 female lecturers who were not leaders.. Purposeful sampling allowed for the selection of those participants who provided the richest information, those who were most interesting and those who manifest the characteristics of most interest to the researchers, (Best and Kahn, 2006). 


\subsubsection{The data collection tools}

Yin (1993) explain that case studies rely on multiple sources of data; including interviews, direct and participant observation, questionnaires, video and audio tapes, internal documents, and artifacts. The qualitative semi structured interview was used to collect data from the female leaders while the questionnaire was used to collect data from male lecturers.

\subsubsection{Ethical considerations}

The researchers were aware of ethical issues involved when one is conducting a research study. These were addressed in the first section of the questionnaire and also before the interview. Informed consent of the respondents and interviewees was sought before the distribution of questionnaire and the interview respectively. This gave the respondents a chance to choose freely whether to proceed or to withdraw from the study. Privacy and confidentiality issues were guaranteed.

\subsubsection{Demographic Data}

\section{Findings}

Table 1: Sex of respondents

$\mathbf{N}=\mathbf{4 0}$

\begin{tabular}{|l|c|c|}
\hline Sex & Number & $\mathbf{\%}$ \\
\hline Males & 20 & 100 \\
\hline Females & 20 & 100 \\
\hline
\end{tabular}

The table above shows that there were equal numbers of respondents in relation to gender. This was a result of the purposive sampling. This helped to come up with a balanced view from both males and females.

\subsection{Representation of female leaders in colleges}

Table 2: Leadership positions occupied by females

$\mathbf{N}=\mathbf{4 0}$

\begin{tabular}{|l|c|c|c|c|c|c|}
\hline \multirow{2}{*}{ Positions occupied by females } & \multicolumn{2}{l|}{ Totals } \\
\cline { 2 - 7 } & Fesponses & \multicolumn{2}{l|}{} \\
\hline Leadership position & No & $\mathbf{\%}$ & $\mathbf{N o}$ & $\mathbf{\%}$ & No & $\mathbf{4 0}$ \\
\hline Principal & 11 & 27.5 & 29 & 72.5 & $\mathbf{4 0}$ & $\mathbf{1 0 0}$ \\
\hline Vice principal & 8 & 20 & 32 & 80 & $\mathbf{4 0}$ & $\mathbf{1 0 0}$ \\
\hline Head Of Department (HOD) & 40 & 100 & 0 & 0 & $\mathbf{4 0}$ & $\mathbf{1 0 0}$ \\
\hline Lecturer in Charge (LIC & 40 & 100 & 0 & 0 & $\mathbf{4 0}$ & $\mathbf{1 0 0}$ \\
\hline
\end{tabular}

The table above shows that $27,5 \%$ of the lecturers agree that there are female principals in their institution while $20 \%$ agree that there are vice principals. All respondents agreed that there are female Heads of Departments (HODs) and Lecturer-in-Charge (LICs) in their institutions. The data showed that the few who indicated that there are female principals and vice principal were from one of the institutions which had the vice principal acting as principal since the male principal was on leave. These data are in line with the conclusion reached by Vosniadou (2004) cited by Mitroussi and Mitroussi (2009) covering all Greek universities for the academic year 2003/2004. Vosniadou (2004) observed that the percentage of women decreases every step up the academic ladder such that as the higher the position in the academic hierarchy, the lower the percentage of women is. The data showed that most female leaders occupy lower levels of leadership while male occupy higher levels of leadership as principal and vice principal.

From the comments given by respondents on female representations, lecturers showed that women representation remains low despite efforts to elevate them through gender equity and equality. One respondent states, "The current number is better than was previously the case. However, the number is still lower than that of male leaders". In the words of one respondent, "female leaders are very few as compared to staff compliment despite having matching academic qualifications to their male counterparts". This showed that despite having same academic qualifications as their male counterparts and constituting a considerable number of the lecturing staff, females are underrepresented. The data collected showed that males occupy the most senior positions of leadership as Principal and Vice Principal while females occupy lower positions as Lecturers in Charge. The response from the interviews confirmed that there is underrepresentation of female leaders in teachers' colleges. This they explained by giving other reasons as lack of opportunity to occupy senior leadership positions and lack of interest on the part of female lecturers. The interviewees also stated,

It is true that women are not well represented in the education sector but the other reason is that most women do not like these positions. Young women like to do those things that give them money quickly like venturing into small businesses other than spending most of the time at work.

This explains the fact that most female lecturers may be interested in conducting money making projects outside the college which may demand more time. Thus when one occupies senior leadership position, 
she will not get time for such moneymaking activities outside the college duties. One would then wonder if it is lack of motivation to take up leadership position of poor remuneration for such leadership positions which distracts females from taking up leadership positions. These findings appear to support the findings by Mitroussi and Mitroussi (2009) in their study on female leadership in education in UK and Greece. They found out that in both countries, fewer women than men reach top rank positions in education, particularly in secondary and higher education and that women are not only under-represented in positions of authority and mainly confined to certain discipline areas. This can be confirmed but the fact that some departments like Home Economics are dominated by females and hence there are female leaders. In addition, Johnson (1993:10) in Husu (2010) reporting on the status of women's leadership in higher education, states that "women administrators continue to be clustered in middle management positions and areas outside of academic deanships and other more central administrative positions". This may help to explain that few women reach the highest level of administration ending up being vices and departmental leaders. It can be noted that the data showed that distribution of leadership positions are not equitable.

However, some responses showed that representation of female in leadership position is up to quiet good as there are a number of females in leadership positions. This can be the result of strides taken by the Government of Zimbabwe to raise female to leadership positions following the need to work on gender equity and equality.

\subsection{Gender differences in leadership styles}

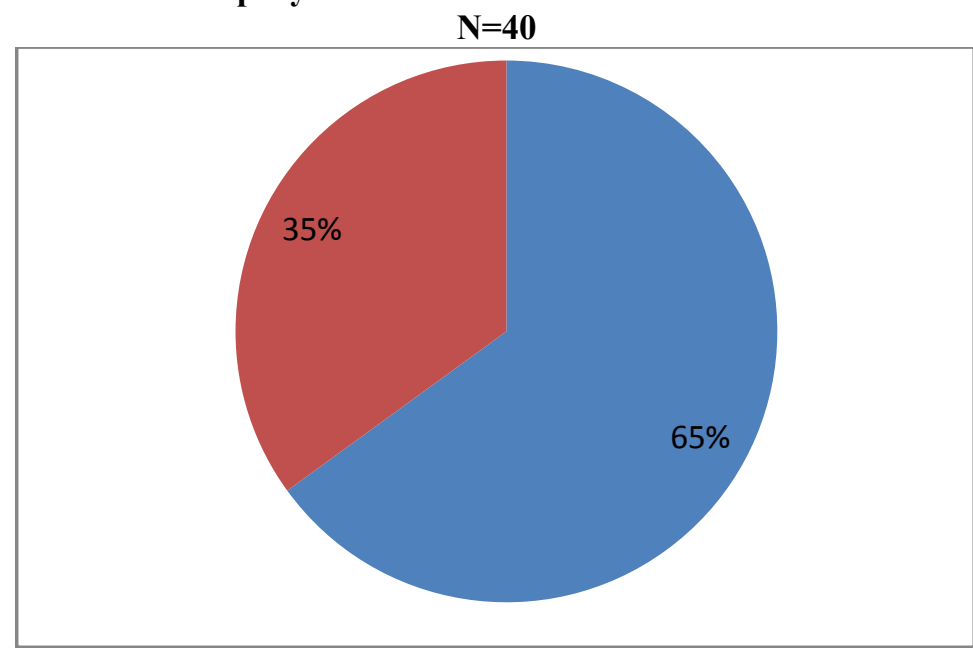

Figure 1: Gender differences in leadership styles

The graph above showed that out of the 40 respondents, $65 \%$ agreed that female leaders are different from male leaders in terms of their leadership styles. Only $35 \%$ showed that male and female leaders are not different in terms of leadership styles.

Those who showed that females are different from males stated that females;

$\circ$ Tend to be vindictive and use an iron hand unnecessarily because they think that they are being looked down upon;

- Rely on information from others and listen to grapevine and hearsay;

- Want to be felt by over stamping authority;

- Tend to be hard on other females than on males;

- Males tend to be more democratic than females;

- Female leaders are motherly, tolerant, honesty and professional than males;

- Use consultative leadership style to gain support from counterparts;

- Are more approachable than males;

- Males are more democratic than females.

These responses are direct words from respondents which showed that males and females are quite different in their leadership styles. This can be further explained by the fact that although male and females are equal, they are different and should be treated and accepted accordingly. This agrees with the view held by Makura (2012) who emphasized the leadership style or model a leader adopts is determined by gender and sex. Men and women are said to differ in their actual social behavior and in the way they are expected to behave in society. This affects their leadership style.

However, $35 \%$ of the respondents indicated that there is no difference between males and females in their leadership styles. The respondents showed that both males and females practice the same leadership styles 
such that both can be autocratic, democratic, transformational or transactional. They further revealed that both can display some traits and emotional character which may influence their leadership styles. One respondent noted, "The leadership styles adopted by people are not necessarily related to sex. Some leadership traits found in males are also found in females". This appears to be linked to the findings by Stanford et al (1995) who observed that what is important is the end result; "it does not make any difference how you lead as long as your leadership style is an effective one". This explains that it does not matter male or female but what matters is the effectiveness of the style adopted. The data gathered from interviews conducted showed that female leaders acknowledge that in as much as they acknowledge the differences they have with their male counterparts; they strongly feel that each person is different such that even male leaders are different from each other. They strongly argued that comparing males and females only served as a way to show that people are not convinced with female leadership. In fact, comparing the two shows the male chauvinist mentality still prevalent in society. One is either a good leader or not regardless of gender. These findings showed that female leaders are different from males in as much as male leaders are different from each other.

Table 3; Evaluation of Female Leaders as Compared to Male Leaders

\begin{tabular}{|l|l|l|l|l|l|l|}
\hline Aspect & No responses & $\begin{array}{l}\text { Very } \\
\text { good }\end{array}$ & good & moderate & poor & Totals \\
\hline Conflict management & & $12.5 \%$ & $32.5 \%$ & $40 \%$ & $15 \%$ & 100 \\
\hline Delegation & & $5 \%$ & $55 \%$ & $27.5 \%$ & $12.5 \%$ & 100 \\
\hline Supervision & & $20 \%$ & $35 \%$ & $35 \%$ & $10 \%$ & 100 \\
\hline Temperament & $5 \%$ & & $30 \%$ & $40 \%$ & $25 \%$ & 100 \\
\hline $\begin{array}{l}\text { Relations } \\
\text { subordinates }\end{array}$ & $10 \%$ & $50 \%$ & $25 \%$ & $15 \%$ & 100 \\
\hline
\end{tabular}

The data shown in the table above showed that most lecturers view female leaders as good at delegation, and relations with subordinates. This was indicated by $55 \%$ and $50 \%$ respondents respectively. Most respondents rated female leaders as moderate in most of the key aspects of their duties as indicated by the responses. Thus, showing that females' performance in leadership is averagely ranked. $15 \%$ of the respondents rated female leaders as poor in conflict management, delegation, supervision, temperament and relations with subordinates. $25 \%$ of respondents showed that females are poor in managing temperament. This can be explained by the emotional character of females which may be misplaced on the subordinates. This showed that female leaders were moderately evaluated in their performance by the lecturers. This gives the impression that female leaders' performance has not satisfied the lecturers who did not rank them as very good. No respondent evaluated female leaders as very good in temperament. Could this be explained by the emotional levels of females or possibly being overburdened by work requirements? The result also showed that there are few lecturers who ranked female leaders as very good in the aspect of their work. The issue of stereotyping cannot be underestimated which may influence the ratings of female leaders.

From the data gathered from interviews, it was noted that female leaders feel that they are competent enough in all areas of their leadership and that those who feel that they are not good enough are just guided by their attitudes towards female leadership. They add that some people do not just trust that female leaders are as good as male leaders so they always want to find fault in the way female leaders perform their duties. Culturally, women's place was at home and in the kitchen while leadership was for males. As a result it became acceptable for leadership of any type to be occupied by males and when females became leaders, it becomes difficult for people to trust that they can be as competent as males. They expressed the view that the major problem to this effect is that their counterparts expect them to behave like their male counterparts of which failure to do that will earn them a moderate performance. This confirms Shavlik and Touchton (1998:101) position when they explained that once women attain leadership positions, they are often expected to "behave just like their male counterparts rather than enhancing their roles with the new and varied talents and fresh perspectives they might bring". Shavlik and Touchton (1998) add that there are gender stereotypes, usually based on historical roles, which often lead to a substantial bias against women and present a major problem for those trying to function as leaders in organizations. This showed that whenever females are in leadership positions, they are expected to satisfy the demands of the position by behaving like male leaders so that people gain confidence in them. If females are to show competence in any leadership position, they are expected to wear male jackets and perform exactly as males do. This way, they would convince people of their capability. This is usually shown by the Shona statement which says, " mukadzi uye murume pachake, or anoita semurume chaiye". In English, it means "this woman performs as good as a man". Thus success was associated with being male such that no female could be successful unless she performs like a man. 


\section{Discussion}

The extent to which females occupy leadership positions in teacher training colleges?

The research found out that females are underrepresented in higher positions of leadership in teacher training colleges. This was shown by the respondents who showed that more females occupy lower leadership positions as HODs, LICs and few females are entrusted with being the principal or vice principal. The females constitute a considerable number of lecturers but still they are underrepresented. This concurs with the findings by Eshete (2003) in the study conducted on females in teacher-training institutions. Eshete (2003) found that females were underrepresented in teacher training institutions despite the fact that they have an advantage of being selected when male and female candidates have equal points on the criteria. Although government policy states that priority should be given to women, in practice no priority is given to women. Possibly, there are no clear and explicit guidelines or practice of admitting women when they fulfill the minimum criteria to a certain leadership post. The posts such as that of principals may be politically guarded and there are usually appointed from the top offices. This supported the need for top government officials to afford females opportunities to occupy such post.

The responses noted a number of reasons for underrepresentation of females. These include the fact that females themselves shun leadership positions because they want to engage in enterprising activities outside the college work and lack of support by counterparts. This confirms the suggestions by Elms (2002) cited by Love (2013) one of the most common reasons for the underrepresentation of women in school administration is gender-role stereotyping. Eshete (2003) concludes that the reasons for women's low representation in higher education are of course many and complex. Some are direct reflections of the personal, social and economic factors. Others are related to the structural, administrative and management structures of the institutions that can also become crucial points for intervention. It should be noted that the study found out that even after women have obtained administrative positions, they are not given the status of the respect given their male colleagues.

\section{Gender differences between male and female leaders?}

The responses indicated that there are indeed gender differences between males and females in terms of leadership as indicated by $65 \%$ and $35 \%$ who said yes and no respectively. The responses showed that by virtue of being socially different, both males and females display different characteristics, traits, behaviors and styles in their leadership. This appears to confirm findings by Makura (2012) that females display communal (feminine) styles whereas males display competitive (masculine) behaviors and in their leadership styles mainly due to their socialization and charismatic differences. Thus the differences between male and female leaders conform to the common gender stereotyping that society ascribes to the two sexes. Therefore, men and women are different such that they approach leadership differently. Elms (2002) cited by Love (2013) who observed that men manage through dominance, authority, influence, and control while women manage by being caring, intuitive, inclusive, and collaborative. This possibly explains the findings from this research study that females tend to be relation-oriented while male are task- oriented. These claims have led to some claims by some lecturers that female leaders tend to use favoritism and gets information from grapevine.

Other respondents showed that males and females are not different at all. They explain this by showing that leadership differs from individual to individual and not necessarily based on gender. This seems to concur with such authors as Stanford et al (1995) who see no effect on gender but are concerned with the effectiveness of the leadership style. He claims that it makes no difference how one leads whether male or female.

Given these arguments it can be noted that lecturers have different view on whether there are gender differences in male and female leadership. This was indicated by the views tabled by respondents with arguments to support their views as discussed above.

\section{Recommendations}

- The government and civil society should work tirelessly to uproot the systems such as patriarchy that wrongly define Zimbabwean society which hinders development. Society is advised to adopt an attitude that believes in the dictum that says "Whatever a man can do a woman can also do." Thus a change of mindset in this regard.

- The government and civil society should continuously run country wide campaign, advocacy and awareness programs to sensitize the nation on issues to do with females in leadership. Interventions in the form of workshops, seminars and in-service training that are specifically aimed at empowering women and men would be useful.

- Government should ensure that such policies such as affirmative action are implemented practically and not only on paper. This can be done by close evaluation and monitoring strategies in most institutions. 
- The Ministry of Higher and Tertiary Education needs to take active steps in combating stereotypes by instituting more rigorous and transparent evaluation processes, as well as educating lecturers and all people in the education sector about stereotyping.

- Some findings are inconclusive such that the study further recommends that there is need for further research in this area so as to generate a sound body of knowledge thus building an understanding of the perceptions and attitudes towards females in leadership. The further study can include the attitude of students as well as the ancillary staff. Also the study may also cover all teacher training colleges in Zimbabwe so as to have a deeper understanding. There is also the need to adopt a different research design and methodology from the case study and mixed methodology used for this study. This might allow for the results to be generalized to a wider population.

\section{References}

[1]. Bass , B. M. (1981). Stogdill's handbook of leadership (rev. ed.). New York: Free Press

[2]. Bass, B. M. (2000). The future of leadership in learning organizations. Journal of Leadership Studies, 7(3), 18-40.

[3]. Best, J.W. and Khan, J.V. (2006).Research in Education. Boston: Allan and Bacon.

[4]. Borg, J.W. and Gall, D.M. (2007). Educational Research: An African Introduction. London, Longman

[5]. Burns, J. M.(1978).Leadership. New York: Harper and Row.

[6]. Cohen, W.A. (1990), The Art of a Leader' Englewood Cliffs, NJ: Prentice Hall

[7]. Cullen, D.L., and Luna, G.(1993).Women mentoring in academe: Addressing the gender gap in higher education. Gender \& Education, 5(2), 125-137.www.wpnet.com/cgi-bin/epwtop/page

[8]. Eagly, A.H , and L.L. Carli, L.L, (2003) The female leadership advantage: An evaluationof the evidence The Leadership Quarterly $14807834 \mathrm{http}$ ///academics.wellesley.edu/Psychology/Faculty/Carli/FemaleLeadershipAdvantage.pdf

[9]. Eshete, A. (2003). Women In Faculties Of Teacher Training Institutions In Ethiopia, Addis

[10]. Ababa; UNESCO International Institute for Capacity Building; www.eng.unesco- iicba.org

[11]. Gardner, H. (1996). Leading Minds: An Anatomy of Leadership. New York: Basic Books,

[12]. Haralambos,M. and Holborn, M. (2000). Sociology: Themes and Perspectives. New York:Harper Collins Publishers

[13]. Johnson, R. B. and Onwuegbuzie, A. J.(2004). Mixed Methods Research: A Research Paradigm Whose Time Has Come. Educational Researcher, 33(7), 14-26.

[14]. Kiamba, J. M. (2006) Women and Leadership Positions: Social and Cultural Barriers to

[15]. Success. http://appwp.cortland.edu/ojs/index.php/wagadu/issue/view/36

[16]. Kimball, M. M.(1995).Feminist visions of gender similarities and differences.

[17]. Binghamton, NY: Haworth Press.

[18]. Klenke, K. (1996). Women and leadership- a contextual perspective. New York:Springer Publishing Company Inc.

[19]. Leedy, P.D. (1980). Practical research; Planning and Design. New York; Macmillan Publishing Company.

[20]. Leedy, P.D. (1993), Practical research; Planning and Design, (fifth edition).

[21]. Columbus; Merril-Prentice Inc

[22]. Moyo. S (2003). The politics of Education. Module MDEA 511. Harare; ZOU.

[23]. Panigrahi, M.R (2013), Perception Of Secondary School Stakeholders Towards Women Representation In Educational Leadership In Harari Region Of Ethiopia , January, 2013 Volume: 2 Issue: 1 Article: 03 ISSN: 2147-0367 International Women Online Journal of Distance Education / www.wojde.org

[24]. Oakley, J. G. (2000). Gender-based Barriers to Senior Management Positions:

[25]. Understanding the Scarcity of Female CEOs. Journal of Business Ethics 27:321-334.

[26]. Outland, E (2010). Challenges of Women in Leadership Roles, Leadership-central, (USA).http://www.leadershipcentral.com/challenges-of-women-in-leadership roles.

[27]. Owens R.G (1995), Organizational Behavior in Education ( $\left.5^{\text {th }}\right)$ edition, Boston, Allayn and Bacon

[28]. Rudenstam, K.E, Newton, R.R. (1992). Surviving your Dissertation: A C omprehensive to Content and Process. London; SAGE Publishers

[29]. Sandler, B.R. (1993). The Campus climate revisited: Chilly for women faculty administrators, and graduate students, in Glazer, S.J. et al.(eds.) Women in higher education: a feminist perspective. Needham Heights: Ginn Press, 175-203

[30]. Sergiovanni, T.J. (1984), "Leadership and excellence in schooling", Educational Leadership, Vol. 41 No. 5, pp. 4-13.

[31]. The Constitution of Zimbabwe, (2013). Zimbabwe Government Printers

[32]. UNFPA (2011), Promoting gender equality and protection of women's rights http://countryoffice.unfpa.org/zimbabwe/2010/11/20/2892/gender/

[33]. UNESCO (1998), Women and Higher Education: Issues and Perspectives; www.eng.unesco-iicba.org

[34]. Winston, B.E and Patterson, K. (2003), An Integrative Definition of Leadership.

[35]. International Journal of leadership Studies,

[36]. https://www.regent.edu/acad/global/publications/ijls/new/volliss2/winston_patterson.doc

[37]. Yin, R.K (2006) Mixed Methods Research: Are the Methods Genuinely Integrated or Merely Parallel? Research in the Schools. Vol. 13, No. 1, pp.41-47

[38]. Zulu ,C.B, (2007) . "A Comparative Study Of Women In Management In Higher

[39]. Education In South Africa And The United Kingdom” http://uir.unisa.ac.za/bitstream/handle/10500/577/thesis.pdf?sequence

[40]. Zulu, C. (2003). Gender representation patterns in higher education management in South Africa. South African Journal of higher education, 17(3):98-104.24 